\title{
Study of the beneficial effect of vanadium sulfate on the liver of experimental diabetic rats
}

\author{
Sevim Tunalı1 (D), Ayșegül Peksel² (i), İnci Arısan² (D), Refiye Yanardağ ${ }^{1}$ (1) \\ ${ }^{1}$ Istanbul University-Cerrahpasa, Faculty of Engineering, Department of Chemistry, Istanbul, Turkey \\ ${ }^{2}$ Yildiz Technical University, Arts and Science Faculty, Department of Chemistry, Istanbul, Turkey
}

ORCID IDs of the authors: S.T. 0000-0003-3363-1290; A.P. 0000-0003-3881-8513; I.A. 0000-0001-8706-0097; R.Y. 0000-0003-4185-4363

Cite this article as: Tunali, S., Peksel, A., Arisan, I., \& Yanardag, R. (2020). Study of the beneficial effect of vanadium sulfate on the liver of experimental diabetic rats. Istanbul Journal of Pharmacy, 50 (3), 211-215.

\begin{abstract}
Background and Aims: Liver is a tissue that is negatively affected by diabetes mellitus (DM). This is due to its central function in the regulation of carbohydrate metabolism. Vanadium salts, which have insulinomimetic effects, have been found to stimulate glycogenesis and glycolysis, as well as to inhibit glycogenolysis and lipolysis. The aim of this study is to evaluate the effect of vanadium sulfate (VS) on biochemical changes in liver tissue of diabetic rats.

Methods: Randomly selected 6.0 - 6.5 months Swiss Albino rats were separated into two diabetic and two control groups. Group I: non treated animals. Group II: non treated animals orally administered VS ( $100 \mathrm{mg} / \mathrm{kg} /$ day for 60 days), group III: STZinduced diabetic animals ( $65 \mathrm{mg} / \mathrm{kg}$ with intraperitoneally) and group IV: STZ-induced diabetic animals administered VS (at same dose and time). Antioxidant enzymes such as catalase, superoxide dismutase, glutathione peroxidase, glutathione reductase, glutathione-S-transferase, as well as alkaline phosphatase, glucose-6-phosphate dehydrogenase, carbonic anhydrase, myeloperoxidase, paraoxonase and lactate dehydrogenase were estimated in liver tissue homogenates of the groups. Results: Liver catalase, superoxide dismutase, glutathione peroxidase, glutathione reductase, glutathione-S-transferase, lactate dehydrogenase, carbonic anhydrase and paraoxonase activities were increased, but alkaline phosphatase, glucose6-phosphate dehydrogenase and myeloperoxidase activities were decreased in diabetic rats when compared to normal rats. Conclusion: Results show that VS restored altered parameters in the liver tissue and prevented oxidative stress in diabetic rats. Keywords: Liver, vanadium sulfate, diabetes mellitus, hyperglycaemia, antioxidant enzymes, streptozotocin, oxidative stress
\end{abstract}

\section{INTRODUCTION}

Hyperglycaemia is the primary clinical indication of diabetic manifestation and is responsible for the development of many chronic diabetic complications. It is associated with long-term microvascular and macrovascular damage, with the dysfunction and failure of various organs, leading to atherosclerosis, blindness, renal failure and neuropathy (Hussain, Claussen, Ramachandran, \& Williams, 2007). Diabetic complications induced by hyperglycaemia are due to free radical generation, thus perturb cellular antioxidant defence systems and damage cells. In a typical diabetic profile, the formation of free radicals is disproportionate. Oxidation of glucose, non-enzymatic gly- cation of proteins, increased transcription factors and oxidative degradation of glycated proteins are the main responsible factors for this occurrence (Pari, \& Saravanan, 2007). Particularly high free radical development and weakening of the antioxidant defence mechanism can cause damage to cell organelles and enzymes, as well as lipid peroxidation and increased insulin resistance (Maritim, Sanders, \& Watkins, 2003).

The liver has a central function in regulating carbohydrate metabolism by maintaining blood sugar level and the continuous supply of glucose to meet the needs of other organs. A significant part of liver damage is caused by reactive oxygen species (ROS) and $\beta$ cell dysfunction, which in turn is damaged by 
autoimmune and inflammatory reactions (Molehin, \& Oloyede, 2018).

Different types of insulin arrangements and synthetic medical remedies are available for clinical use in diabetic patients. Unfortunately, none of the available treatment strategies restores the release of physiological insulin, or has an effect in healing the cellular lesions caused by diabetes. As current treatments produce undesirable side effects and contraindications, the necessity of new approaches to DM treatment has arisen (Wagenaar, Kuck, \& Hoekstra, 1999; Luft, Schmülling, \& Eggstein, 1978). A variety of vanadium compounds have been shown to have insulinomimetic properties in animal model and cell culture systems. They exhibit great potential for the pharmacotherapy of diabetes (Yanardag, et al., \& Bolkent, 2009; Zhang, Yang, Wang, \& Crans, 2006)

Vanadium is an essential element which is responsible of regulation in biological systems. Just like other essential micronutrients, this ultra-trace element is required in small quantities for the cells to maintain their normal functions and growth and development of healthy organisms. It affects the activity of enzymes, adjust the second messengers actions, some signal transduction cascades and carbohydrate metabolism, mimics insulin and growth factor activities, induce protein tyrosine kinase activity, decrease phosphotyrosine phosphatases and regulate expression of genes (Chakraborty et al., 2007). Vanadium ions and its complexes exert various insulinomimetic and anti-diabetic properties, for instance increasing glucose transport in the liver tissue and skeletal muscle, stimulating the glycogen synthesis and lipogenesis as well as adipocyte metabolism, and inhibiting lipolysis and protein catabolism (Gao et al., 2006). Previous investigations indicate that vanadium compounds inhibit protein tyrosine phosphatase activity (an enzyme involved in the direct phosphorylation of insulin receptor substrate 1 , stimulation of insulin receptor and cytosolic non-receptor tyrosine kinase activity, as well as the activation of phosphatidylinositol 3 kinase) leading to glucose transporter 4 (GLUT4) translocation (Kawabe, Yoshikawa, Adachi, \& Sakurai, 2006).

The present study was carried out to evaluate the effect of vanadium sulfate (VS) on biochemical changes in liver tissue of diabetic rats. Our aim is to focus on the beneficial effect of VS on the oxidatively damaged liver tissue of streptozotocin (STZ)-induced diabetic rats.

\section{MATERIALS AND METHODS}

\section{Experimental rats}

In this study, 6.0-6.5 month old male rats were used. All animals were kept in cages at standard conditions.

\section{Induction of diabetes}

The rats were made diabetic with a single dose of streptozotocin (STZ). STZ were $(65 \mathrm{mg} / \mathrm{kg})$ dissolved in a freshly solution

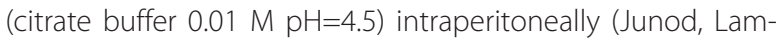
bert, Stauffacher, \& Renold, 1969). The data releated with blood glucose concentrations were are presented in our previous study (Koyuturk, Tunali, Bolkent, \& Yanardag, 2005).

\section{Experimental design}

The experiments were examined and confirmed by the Local Institute's Animal Care and Use Committees of Istanbul University. Four groups were randomly created; group I untreated, nondiabetic controls ( $n=13$ ); group II nondiabetic control animals administered VS ( $n=5)$; group III diabetes induced animals with STZ ( $n=11)$; group IV STZ-induced diabetic animals administered with VS ( $n=11)$. VS was given $(100 \mathrm{mg} / \mathrm{kg} /$ day) for 60 days without interruption by gavage technique. Blood glucose concentrations were determined according to the otoluidine method (Relander, \& Räihä, 1963).

\section{Preparation of liver tissue homogenates}

At 60 days all fasted animals were sacrificed under anesthesia. Liver tissues were taken, washed with cold solution $(0.9 \%$ saline) and frozen until needed for study at $-76^{\circ} \mathrm{C}$. After made $10 \%(\mathrm{w} / \mathrm{v})$ homogenate with glass equipment, clear supernatants were obtained by centrifugation and used for analysis of enzymatic antioxidants, tissue enzyme activities and protein level estimation.

\section{Assay of liver enzymes activities and protein level}

Freshly prepared homogenates were used to assay for enzyme activities as follows: catalase (CAT) (Aebi, 1984), superoxide dismutase (SOD) (Mylorie, Collins, Umbles, \& Kyle, 1986), glutathione peroxidase (GPX) (Paglia, \&Valentine, 1967), glutathione reductase (GR) (Beutler, 1971), glutathione-S-transferase (GST) (Habig, 1981), alkaline phosphatase (ALP) (Walter, \& Schult, 1974), glucose-6-phosphate dehydrogenase (G6PD) (Betke et al., 1967), lactate dehydrogenase (LDH) (Wroblewski, 1957), carbonic anhydrase (CA) (Verpoorte, 1967), myeloperoxidase (MPO) (Wei, \& Frenkel, 1991) and paraoxonase (PON) (Furlong, Richter, Seidel, \& Motulsky, 1988). Liver protein level was measured by the method of Lowry using bovine serum albumin as standard (Lowry, Rosebrough, Farr, \& Randall, 1951).

\section{Statistical data}

The unpaired Student's t-test and analysis of variance (ANOVA) were used to analyse biochemical results calculated with statistical computer package (NCSS). Mann-Whitney test was used for comparison between control and experimental animals. The results were performed as mean \pm SD. $p<0.05$ values were accepted as significant.

\section{RESULTS}

Table 1 shows the activities of antioxidant enzymes in all groups. A significant decrease in CAT, SOD, GPx, GR and GST activities in liver tissue of STZ-diabetic group compared to control group ( ${ }^{\mathrm{a}}<0.0001$ ) was observed. The activities of the enzymes were increased in diabetic group given VS compared to nontreated diabetic group ( $\left.{ }^{\mathrm{b} P}<0.0001\right)$. A significant difference was observed between all groups $\left(P_{\text {ANOVA }}=0.0001\right.$; Table 1$)$.

Liver tissue ALP, G6PDH and LDH activities were significantly increased $\left({ }^{\mathrm{P}}<0.0001\right)$ in diabetic rats as compared to the control group. Orally given VS was meaningfully reduced liver ALP, G6P$\mathrm{DH}$ and LDH activities ( ${ }^{\mathrm{b}} \mathrm{P}<0.0001, \mathrm{C} P<0.001$ ) when compared to diabetic rats. All enzymatic activities were observed to have significant difference between the groups $\left(P_{\text {ANOVA }}=0.0001\right.$; Table 2$)$. 
Table 1. Liver CAT, SOD, GPx, GR and GST activities of control and diabetic rats.*

\begin{tabular}{|c|c|c|c|c|c|}
\hline Groups & $\begin{array}{c}\text { CAT } \\
\text { (U/mg protein) }\end{array}$ & $\begin{array}{c}\text { SOD } \\
\text { (U/mg protein) }\end{array}$ & $\begin{array}{c}\text { GPx } \\
\text { (U/gprotein) }\end{array}$ & $\begin{array}{c}\text { GR } \\
\text { (U/mg protein) }\end{array}$ & $\begin{array}{c}\text { GST } \\
\text { (U/mg protein) }\end{array}$ \\
\hline Control & $2733.25 \pm 65.34$ & $2.91 \pm 0.39$ & $3632.18 \pm 69.5$ & $0.0232 \pm 0.0008$ & $3.85 \pm 0.04$ \\
\hline Control + VS & $3080.93 \pm 118.86$ & $1.82 \pm 0.32$ & $3351.84 \pm 31.62$ & $0.0188 \pm 0.0006$ & $4.37 \pm 0.06$ \\
\hline Diabetic & $1526.74 \pm 50.31^{\mathrm{a}}$ & $1.92 \pm 0.14^{\mathrm{a}}$ & $2187.58 \pm 65.79^{a}$ & $0.0130 \pm 0.0003^{a}$ & $2.29 \pm 0.06^{\mathrm{a}}$ \\
\hline Diabetic + VS & $2722.35 \pm 107.18^{b}$ & $3.20 \pm 0.15^{b}$ & $3890.72 \pm 45.92^{b}$ & $0.0250 \pm 0.0003^{b}$ & $3.80 \pm 0.06^{b}$ \\
\hline$P_{\text {ANOVA }}$ & 0.0001 & 0.0001 & 0.0001 & 0.0001 & 0.0001 \\
\hline
\end{tabular}

\section{Table 2. Liver ALP, G6PDH and LDH activities of} control and diabetic rats*.

\begin{tabular}{|lccc|}
\hline Groups & $\begin{array}{c}\text { ALP } \\
\text { (U/mg protein) }\end{array}$ & $\begin{array}{c}\text { G6PDH } \\
\text { (U/g protein) }\end{array}$ & $\begin{array}{c}\text { LDH } \\
\text { (U/mg protein) }\end{array}$ \\
\hline Control & $4.40 \pm 0.88$ & $5.10 \pm 0.40$ & $38.36 \pm 3.71$ \\
Control+VS & $7.53 \pm 1.32$ & $6.25 \pm 0.12$ & $26.68 \pm 7.32$ \\
Diabetic & $8.24 \pm 0.80^{\mathrm{a}}$ & $7.90 \pm 0.28^{\mathrm{a}}$ & $119.57 \pm 7.99^{\mathrm{a}}$ \\
Diabetic + VS & $4.94 \pm 0.48^{\mathrm{b}}$ & $5.68 \pm 0.18^{\mathrm{b}}$ & $87.61 \pm 13.64^{\mathrm{c}}$ \\
$\mathrm{P}_{\text {ANOVA }}$ & 0.0001 & 0.0001 & 0.0001 \\
\hline${\text { * Mean } \pm \mathrm{SD} \text {, }{ }^{\text {aP }}<0.0001 \text { compared to control rats, }}^{\mathrm{b} P}<0.0001$ com- $^{-}$ \\
pared to diabetic rats, ${ }^{\mathrm{C} P}<0.001$ compared to diabetic rats. \\
\hline
\end{tabular}

Liver CA, MPO and PON activities of control and diabetic rats are presented in Table 3. The liver CA and PON activities at 60 days of diabetes induction showed a significant decrease when compared to control rats ( $\left.{ }^{\mathrm{P}}<0.0001\right)$. Treatment with VS significantly reversed the altered activities of CA and PON of the diabetic rats in comparison to non-treated diabetic animals ( $\left.{ }^{\mathrm{b} P}<0.0001\right)$. On the other hand, experimentally-induced diabetes caused a mean increase in liver MPO activity ( $\mathrm{P}<0.0001)$ in comparison to control animals. Orally vanadyl treated diabetic group demonstrated significant decrease in MPO activity when compared with STZ-induced diabetic group ( ${ }^{\mathrm{b} P}<0.0001$ ). A significant difference was observed between treated and non-treated animals $\left(P_{\text {ANOVA }}=0.0001\right.$; Table 3$)$.

\section{Table 3. Liver CA, MPO and PON activities of control and diabetic rats.*}

\begin{tabular}{|lccc|}
\hline Groups & $\begin{array}{c}\text { CA } \\
\text { (U/mg protein) }\end{array}$ & $\begin{array}{c}\text { MPO } \\
\text { (U/g protein) }\end{array}$ & $\begin{array}{c}\text { PON } \\
\text { (U/g protein) }\end{array}$ \\
\hline Control & $7.58 \pm 1.42$ & $0.41 \pm 0.09$ & $21.22 \pm 2.44$ \\
Control + VS & $4.00 \pm 0.94$ & $0.57 \pm 0.01$ & $20.38 \pm 1.06$ \\
Diabetic & $3.98 \pm 0.50^{\mathrm{a}}$ & $0.60 \pm 0.01^{\mathrm{a}}$ & $15.93 \pm 0.55^{\mathrm{a}}$ \\
Diabetic + VS & $6.96 \pm 0.86^{\mathrm{b}}$ & $0.26 \pm 0.03^{\mathrm{b}}$ & $19.12 \pm 1.50^{\mathrm{b}}$ \\
$\mathrm{P}_{\text {ANOVA }}$ & 0.0001 & 0.0001 & 0.0001 \\
\hline *Mean \pm SD, aP $<0.0001$ compared to control rats, ${ }^{\mathrm{D} P}<0.0001$ com- \\
pared to diabetic rats.
\end{tabular}

\section{DISCUSSION}

Oxidative stress, resulting from the production of uncontrolled reactive oxygen species (ROS) is a condition that is attributed and accepted in the aetiology of diabetes. Alterations in the antioxidant enzymes activities makes tissues defenceless to oxidative stress and this leads to the onset and progression of diabetes complications (Pandey \& Rizvi, 2009; Lipinski, 2001).

Increased ROS production due to persistent hyperglycaemia may lead to a decrease in hepatic antioxidant enzyme activities and depletion of hepatic antioxidants. Treatment with VS significantly improved CAT, SOD and GSH related enzymatic activities (GPx, GR and GST) in hepatic system. The observed results may be attributable to the antioxidant activity of VS.

It was found in our previous work that VS treatment alleviated some liver tissue alterations such as decreased level of reduced glutathione (GSH) that are associated with diabetic state (Koyuturk et al., 2005). This could indicate an increase in activities of antioxidant enzymes of the liver tissue, suggests the normal functioning and protective activity of vanadium and supports the hepatoprotective efficacy of VS.

ALP is an enzyme indicator of hepatic lesion and a biomarker for acute hepatotoxicity in type 1 DM (Rodríguez, Plavnik, \& Tolosa de Talamoni, 2018; Kanikarla-Marie \& Jain, 2015; Liang et al., 2015). The increased activity of liver ALP activity suggest defective utilization of glucose. The administration of VS in our study normalized the ALP activity in the diabetic liver tissue.

The fate of glucose through the pentose phosphate pathway has not been well characterized, more so there is conflicting evidence about the activity of G6PDH in DM. Gupte et al., (2009) demonstrated that the expression of protein level and activity of G6PDH is much higher in the liver in the type $2 \mathrm{DM}$ Zucker obese rats (Gupte et al., 2009). Accordingly, in the present study, we observed an increased G6PDH activity in diabetic liver tissue. The higher G6PDH activities drive NADPH - a fuel of $\mathrm{NADPH}$ oxidase, and $\mathrm{O}_{2}^{-}$production. The studies suggest that this is one of the reasons of increased oxidative stress in multiorgan dysfunction and damage in experimental diabetic rats (Gupte et al., 2009; Gupte et al., 2005; Matsui et al., 2005). In our study, oral vanadium supplementation decreased significantly the activity of this enzyme in hepatic tissue, thus highlighting another possible mechanism of anti diabetogenic activity. 
The lactic acid formation from pyruvate is catalysed by LDH, a cytosolic enzyme in anaerobic glycolysis pathway. In hyperglycemic state, a significant increase in LDH activity was found due to impaired glucose-induced insulin secretion in diabetes (Ainscow, Zhao \& Rutter, 2000). The LDH system reflects $\mathrm{NAD}^{+}$/ $\mathrm{NADH}$ ratio indicated by the lactate/pyruvate ratio of the hepatocyte cytosol (Sekar, Sivagnanam \& Subramanian, 2005). Similarly, in the present study, a significant increase in LDH activity of was observed in the diabetic group. A significant reduction in the LDH activity was observed due to the regulation of the ratio of $\mathrm{NAD}^{+} / \mathrm{NADH}$ by oxidation of blood glucose, in VS given diabetic rats.

CA is involved in many important physiological and pathological conditions, and provides $\mathrm{HCO}_{3}{ }^{-}$as a substrate for pyruvate carboxylase (Ismail, 2018). It is reported that the concentration of CA-III is reduced in the liver and serum of STZ-induced DM adult male rats (Nishita, Igarashi, \& Asari, 1995). In our study, oral VS treatment increased the CA activity in diabetic rats. This increase may lead to increased hepatic glucose production by the presence of these substrates.

Increased MPO production in neutrophilic granulocytes can produce strong oxidants (such as $\mathrm{HOCl}, \mathrm{HOBr}$ ), provoke oxidation of nitric oxide and nitration of tyrosine. This MPOderived reactive species could eventually mediate the development of oxidative damages in liver tissue. Wiersma et al., (2008) suggested that type 2 DM is associated with mildly increased plasma levels of MPO. In our research, we observed a significant increase in MPO activity in the diabetic tissue. Antioxidant effect of vanadium decreased MPO activity and this suggest a reduction in oxidative stress and subsequent neutrophil production.

PON1 plays an important role in the regulation of glucose metabolism. In the muscles, GLUT4 expression is upregulated by PON1 in an insulin receptor-independent manner (KorenGluzer, Aviram \& Hayek, 2013). Besides that, PON1 regulates directly some important enzymes of glycolytic pathway, (Meneses, Silvestre, Sousa-Lima, \& Macedo, 2019; Koren-Gluzer et al., 2013; Khersonsky \& Tawfik, 2006). Our data showed that VS significantly increased the activity of PON, an enzyme mainly synthesized in the liver tissue.

\section{CONCLUSION}

In conclusion, the findings of the current study demonstrate that VS may provide effective protection against oxidative damage in liver tissue of STZ-induced diabetic rats. This suggests that vanadium is able to ameliorate the enzymatic antioxidant defence systems and prevent peroxidation in tissue. VS significantly improved metabolic alterations, oxidative and inflammatory status in liver tissue through its antidiabetic, antioxidative and anti-inflammatory effects. Therefore, VS could be an ideal auxiliary treatment option for DM.

Peer-review: Externally peer-reviewed.

Author Contributions: Conception/Design of Study- S.T., A.P., I.A., R.Y.; Data Acquisition- S.T., A.P.; Data Analysis/Interpretation- S.T., A.P., I.A., R.Y.; Drafting Manuscript- S.T., A.P., R.Y.; Critical Revision of Manuscript-
S.T., R.Y.; Final Approval and Accountability- S.T., A.P., I.A., R.Y.; Technical or Material Support- S.T., A.P.; Supervision- R.Y.

Conflict of Interest: The authors have no conflict of interest to declare.

Financial Disclosure: Authors declared no financial support.

\section{REFERENCES}

- $\quad$ Aebi, H. (1984). Catalase in vitro. In: Methods of enzymatic analysis, 2nd Edition, Vol.2, Bergmeyer H.U. (Ed.), pp. 121-126.

Ainscow, E. K., Zhao, C., \& Rutter, G. A. (2000). Acute overexpression of lactate dehydrogenase-A perturbs beta-cell mitochondrial metabolism and insulin secretion. Diabetes, 49, 1149-1155. https://doi.org/10.2337/diabetes.49.7.1149

- Betke, K., Beutler, E., Brewer, G. J., Kirkman, H. N., Luzzatto, L., Motulsky, A. G., Ramot, B., Siniscalco, M. (1967). Standardization of procedures for the study of glucose-6-phosphate dehydrogenase. Report of a WHO Scientific Group. World Health Organization Technical Report Series, 366, 1-53.

- Beutler, E. (1971). Red cell metabolism. A manual of biochemical methods, vol. 12. London: Academic Press.

- Chakraborty, T., Chatterjee, A., Rana, A., Dhachinamoorthi, D., Kumar P, A., \& Chatterjee, M. (2007). Carcinogen-induced early molecular events and its implication in the initiation of chemical hepatocarcinogenesis in rats: chemopreventive role of vanadium on this process. Biochimica et Biophysica Acta, 1772, 48-59. https://doi.org/10.1016/j.bbadis.2006.10.019

- $\quad$ Furlong, C. E., Richter, R. J., Seidel, S. L., \& Motulsky, A. G. (1988). Role of genetic polymorphism of human plasma paraoxonase/ arylesterase in hydrolysis of the insecticide metabolites chlorpyrifos oxon and paraoxon. American Journal of Human Genetics, 43, 230-238.

- $\quad$ Gao, L. H., Liu, W. P., Wang, B. L., Li, L., Xie, M. J., Li, Y. R., Chen, Z. H., \& Chen, X. Z. (2006). Effects of bis(alpha-furancarboxylato) oxovanadium(IV) on non-diabetic and streptozotocin-diabetic rats. Clinica Chimica Acta; International Journal of Clinical Chemistry, 368, 173-178. https://doi.org/10.1016/j.cca.2005.12.028

- $\quad$ Gupte, R. S., Floyd, B. C., Kozicky, M., George, S., Ungvari, Z. I., Neito, V., Wolin, M. S., \& Gupte, S. A. (2009). Synergistic activation of glucose-6-phosphate dehydrogenase and $\mathrm{NAD}(\mathrm{P}) \mathrm{H}$ oxidase by Src kinase elevates superoxide in type 2 diabetic, Zucker fa/fa, rat liver. Free Radical Biology \& Medicine, 47, 219-228. https://doi. org/10.1016/j.freeradbiomed.2009.01.028

Gupte, S. A., Kaminski, P. M., Floyd, B., Agarwal, R., Ali, N., Ahmad, M., Edwards, J., \& Wolin, M. S. (2005). Cytosolic NADPH may regulate differences in basal Nox oxidase-derived superoxide generation in bovine coronary and pulmonary arteries. American Journal of Physiology. Heart and Circulatory Physiology, 288, H13-H21. https://doi.org/10.1152/ajpheart.00629.2004

- Habig, W. H., \& Jakoby, W. B. (1981). Assays for differentiation of glutathione S-transferases. Methods in Enzymology, 77, 398-405. https://doi.org/10.1016/s0076-6879(81)77053-8

Hussain, A., Claussen, B., Ramachandran, A., \& Williams, R. (2007). Prevention of type 2 diabetes: a review. Diabetes Research and Clinical Practice, 76, 317-326. https://doi.org/10.1016/j.diabres.2006.09.020

Ismail I. S. (2018). The role of carbonic anhydrase in hepatic glucose production. Current Diabetes Reviews, 14, 108-112. https:// doi.org/10.2174/1573399812666161214122351

- Junod, A., Lambert, A. E., Stauffacher, W., \& Renold, A. E. (1969). Diabetogenic action of streptozotocin: relationship of dose to metabolic response. The Journal of Clinical Investigation, 48, 21292139. https://doi.org/10.1172/JCl106180 
- $\quad$ Kanikarla-Marie, P., \& Jain, S. K. (2015). Role of hyperketonemia in inducing oxidative stress and cellular damage in cultured hepatocytes and type 1 diabetic rat liver. Cellular Physiology and Biochemistry: International Journal of Experimental Cellular Physiology, Biochemistry, and Pharmacology, 37, 2160-2170. https://doi. org/10.1159/000438573

- $\quad$ Kawabe, K., Yoshikawa, Y., Adachi, Y., \& Sakurai, H. (2006). Possible mode of action for insulinomimetic activity of vanadyl(IV) compounds in adipocytes. Life Sciences, 78, 2860-2866. https://doi. org/10.1016/j.lfs.2005.11.008

- Khersonsky, O., \& Tawfik, D. S. (2006). The histidine 115-histidine 134 dyad mediates the lactonase activity of mammalian serum paraoxonases. The Journal of Biological Chemistry, 281, 7649-7656. https://doi.org/10.1074/jbc.M512594200

- Koren-Gluzer, M., Aviram, M., \& Hayek, T. (2013). Paraoxonase1 (PON1) reduces insulin resistance in mice fed a high-fat diet, and promotes GLUT4 overexpression in myocytes, via the IRS-1/Akt pathway. Atherosclerosis, 229, 71-78. https://doi.org/10.1016/j. atherosclerosis.2013.03.028

- $\quad$ Koyuturk, M., Tunali, S., Bolkent, S., \& Yanardag, R. (2005). Effects of vanadyl sulfate on liver of streptozotocin-induced diabetic rats. Biological Trace Element Research, 104, 233-247. https://doi. org/10.1385/BTER:104:3:233

- $\quad$ Liang, T., Zhang, Q., Sun, W., Xin, Y., Zhang, Z., Tan, Y., Zhou, S., Zhang, C., Cai, L., Lu, X., \& Cheng, M. (2015). Zinc treatment prevents type 1 diabetes-induced hepatic oxidative damage, endoplasmic reticulum stress, and cell death, and even prevents possible steatohepatitis in the OVE26 mouse model: Important role of metallothionein. Toxicology Letters, 233, 114-124. https://doi. org/10.1016/j.toxlet.2015.01.010

- Lipinski, B. (2001). Pathophysiology of oxidative stress in diabetes mellitus. Journal of Diabetes and its Complications, 15, 203-210. https://doi.org/10.1016/s1056-8727(01)00143-x

- Lowry, O. H., Rosebrough, N. J., Farr, A. L., \& Randall, R. J. (1951). Protein measurement with the Folin phenol reagent. The Journal of Biological Chemistry, 193, 265-275.

- $\quad$ Luft, D., Schmülling, R. M., \& Eggstein, M. (1978). Lactic acidosis in biguanide-treated diabetics: a review of 330 cases. Diabetologia, 14, 75-87. https://doi.org/10.1007/BF01263444

- Maritim, A. C., Sanders, R. A., \& Watkins, J. B., 3rd (2003). Diabetes, oxidative stress, and antioxidants: a review. Journal of Biochemical and Molecular Toxicology, 17, 24-38. https://doi.org/10.1002/ jbt.10058

- Matsui, R., Xu, S., Maitland, K. A., Hayes, A., Leopold, J. A., Handy, D. E., Loscalzo, J., \& Cohen, R. A. (2005). Glucose-6 phosphate dehydrogenase deficiency decreases the vascular response to angiotensin II. Circulation, 112, 257-263. https://doi.org/10.1161/ CIRCULATIONAHA.104.499095

- Meneses, M. J., Silvestre, R., Sousa-Lima, I., \& Macedo, M. P. (2019). Paraoxonase-1 as a regulator of glucose and lipid homeostasis: Impact on the onset and progression of metabolic disorders. International Journal of Molecular Sciences, 20, 4049. https://doi. org/10.3390/ijms20164049

- Molehin, O. R., \& Oloyede, O. I. (2018). Attenuation of oxidative stress and hepatic damage by white butterfly (Clerodendrum volubile) leaves in streptozotocin-induced diabetes in rats. Journal of Basic and Clinical Physiology and Pharmacology, 30, 81-89. https://doi.org/10.1515/jbcpp-2018-0083

- Mylorie, A. A., Collins, H., Umbles, C., Kyle, J. (1986). Erythrocyte superoxide dismutase activity and other parameters of copper status in rats ingesting lead acetate. Toxicology and Applied Pharmacology, 82, 512-520
Nishita, T., Igarashi, S., \& Asari, M. (1995). Determination of carbonic anhydrase-III by enzyme-immunoassay in liver, muscle and serum of male rats with streptozotocin-induced diabetes mellitus. The International Journal of Biochemistry \& Cell Biology, 27, 359-364. https://doi.org/10.1016/1357-2725(94)00090-x

- Paglia, D. E., \& Valentine, W. N. (1967). Studies on the quantitative and qualitative characterization of erythrocyte glutathione peroxidase. The Journal of Laboratory and Clinical Medicine, 70, 158-169.

- Pandey, K. B., \& Rizvi, S. I. (2009). Plant polyphenols as dietary antioxidants in human health and disease. Oxidative Medicine and Cellular Longevity, 2, 270-278. https://doi.org/10.4161/oxim.2.5.9498 Pari, L., \& Saravanan, R. (2007). Beneficial effect of succinic acid monoethyl ester on erythrocyte membrane bound enzymes and antioxidant status in streptozotocin-nicotinamide induced type 2 diabetes. Chemico-Biological Interactions, 169, 15-24. https://doi. org/10.1016/j.cbi.2007.04.010

- Rains, J. L., \& Jain, S. K. (2011). Oxidative stress, insulin signaling, and diabetes. Free Radical Biology \& Medicine, 50, 567-575. https:// doi.org/10.1016/j.freeradbiomed.2010.12.006

Relander, A., \& Räihä C. E. (1963) Differences between the enzymatic and o-toluidine methods of blood glucose determination. Scandinavian Journal of Clinical and Laboratory 15, 221-224

Rodríguez, V., Plavnik, L., \& Tolosa de Talamoni, N. (2018). Naringin attenuates liver damage in streptozotocin-induced diabetic rats. Biomedicine \& Pharmacotherapy = Biomedecine \& Pharmacotherapie, 105, 95-102. https://doi.org/10.1016/j.biopha.2018.05.120

- Sekar, D. S., Sivagnanam, K., \& Subramanian, S. (2005). Antidiabetic activity of Momordica charantia seeds on streptozotocin induced diabetic rats. Die Pharmazie, 60, 383-387.

- Verpoorte, J. A., Mehta, S., \& Edsall, J. T. (1967). Esterase activities of human carbonic anhydrases B and C. The Journal of Biological Chemistry, 242, 4221-4229.

- Wagenaar, L. J., Kuck, E. M., \& Hoekstra, J. B. (1999). Troglitazone. Is it all over?. The Netherlands Journal of Medicine, 55, 4-12. https:// doi.org/10.1016/s0300-2977(99)00021-2

Walter, W., \& Schult, C. (1974). In: Methods of Enzymatic Analysis, Vol.2, Bergmeyer H.U., pp. 856-886.

- Wei, H., \& Frenkel, K. (1991). In vivo formation of oxidized DNA bases in tumor promoter-treated mouse skin. Cancer Research, 51, 4443-4449.

- $\quad$ Wiersma, J. J., Meuwese, M. C., van Miert, J. N., Kastelein, A., Tijssen, J. G., Piek, J. J., \& Trip, M. D. (2008). Diabetes mellitus type 2 is associated with higher levels of myeloperoxidase. Medical Science Monitor: International Medical Journal of Experimental and Clinical Research, 14, CR406-CR410.

- Wroblewski F. (1957). Clinical significance of serum enzyme alterations associated with myocardial infarction. American Heart Journal, 54, 219-224. https://doi.org/10.1016/0002-8703(57)90149-7 Yanardag, R., Demirci, T. B., Ulküseven, B., Bolkent, S., Tunali, S., \& Bolkent, S. (2009). Synthesis, characterization and antidiabetic properties of N(1)-2,4-dihydroxybenzylidene-N(4)-2-hydroxybenzylidene-S-methyl-thiosemicarbazidato-oxovanadium (IV). European Journal of Medicinal Chemistry, 44, 818-826. https://doi. org/10.1016/j.ejmech.2008.04.023

- $\quad$ Zhang, Y., Yang, X. D., Wang, K., \& Crans, D. C. (2006). The permeability and cytotoxicity of insulin-mimetic vanadium (III,IV,V)-dipicolinate complexes. Journal of Inorganic Biochemistry, 100, 80-87. https://doi.org/10.1016/j.jinorgbio.2005.10.006 